Rev. Biol. Neotrop. 5(1): 41-51, 2008

\title{
LLOMETRIC VARIATION OF SHADE-TOLERANT TREE SPECIES IN A MEXICAN TROPICAL RAIN FOREST
}

\author{
José Luis MARTínez-SÁNCHez \\ División Académica de Ciencias Biológicas, Universidad Juárez Autónoma de Tabasco, km 0.5 \\ Carr. Villahermosa-Cárdenas, Villahermosa, Tab. 86990, México; \\ e-mail: jose.martinez@dacbiol.ujat.mx
}

\begin{abstract}
AвstRACT: In tropical rain forests, shade-tolerant tree species exhibit the typical wide-crown architectural type characteristic of low-light environments. In recent studies, though, some shade-tolerant species have been found not to show this typical architectural type. In the present study, the stem and crown architectural type of three shade-tolerant tree species was analyzed, two from the forest understorey and one from the mid-canopy. Twelve architectural variables were measured in 254 saplings between $50 \mathrm{~cm}$ and $300 \mathrm{~cm}$ tall in Los Tuxtlas, México. The allometric analysis showed that the three species are not similar in architecture. Instead, they present architectural differences related to their adult canopy position. Both sub-canopy species presented thicker stems and flatter crowns, while the mid-canopy species was taller, presenting a slenderer stem and crown, and a less vertical crown shading. It is concluded that within the group of shade-tolerant tree species there is certainly more than a single architectural crown type depending on the adult canopy position of the particular species. The previous single wide-crown architectural type is not the only or typical architectural type for shade-tolerant species.
\end{abstract}

KEY wORDs: Mexico, phenotypic plasticity, tree architecture, tree growth type, tree morphology.

Resumo: Nas florestas tropicais úmidas, as espécies arbóreas tolerantes a sombra apresentam arquitetura típica de copa ampla característica de ambientes sombreados. Em estudos recentes, porém, observou-se que algumas espécies tolerantes a sombra não apresentam esta arquitetura típica. Neste estudo, a arquitetura de três espécies arbóreas tolerantes a sombra, duas de sub-bosque e uma de dossel médio, foi analisada. Para isso, foram medidas 12 variáveis de arquitetura de 254 árvores juvenis entre $50 \mathrm{~cm}$ e $300 \mathrm{~cm}$ de altura em Los Tuxtlas, México. A análise alométrica mostrou que a arquitetura das três espécies não é igual; pelo contrário, elas apresentam diferenças em arquitetura dependendo de sua posição no dossel florestal quando adultas. Ambas as espécies de sub-bosque apresentaram caule mais grosso e copa mais plana, enquanto a espécie de dossel médio apresentou-se mais alta e com caule mais delgado, copa mais elongada e menos sombra foliar no interior da copa. Conclui-se que no grupo das espécies arbóreas tolerantes a sombra existe mais de um tipo de arquitetura de copa, dependendo da posição que cada espécie em particular ocupa no dossel na fase adulta. O modelo de arquitetura de copa ampla, considerado previamente, não é típico nem único para as espécies tolerantes a sombra.

Palavras-chave: México, plasticidade fenotípica, arquitetura de árvores, tipo de crescimento de árvores, morfologia arbórea.

\section{INTRODUCTION}

$\mathrm{T}$ Iree architecture, to a great extent, represents the leaf display in the crown, which is strongly influenced by the ontogeny and environment where the tree grows. Its importance relies on the ability to efficiently acquire and use carbon for future growth and survival (Bongers \& Sterck, 1998).

Allometry (relationship between different dimensions or sizes within an organism) results of differential allocation of carbon to different parts of the tree, and has been found to be related to the growth strategy of tropical trees. Trees that grow towards the canopy invest more in height and are relatively slenderer. Trees in the dark understorey invest more in leaf display minimizing self-shading, thus producing relatively wide crowns to capture as much light as possible (Bongers \& Sterck, 1998).

Light resource has been one of the major ecological factors in the classification of tree 
species in tropical forests. The natural ability of the tree species to regenerate in shade and light environments has led to the long-prevailing simple classification of shade-tolerant and shade-intolerant (or pioneer) species.

Shade-tolerant species have shorter and thicker trunks and a higher above-ground biomass allocation. Their adaptation to low-light environments would reduce self-shading by having shallow, monolayered crowns (Kohyama 1987, 1991). In contrast, pioneer species have narrow crowns to enhance vertical height growth and out-compete their neighbors (King et al., 1997; Turner et al., 1995).

In tropical rain forests, the variability of crown architecture in these functional groups of species remains unclear. In the 1970's, shade-tolerant species were seen as a homogeneous group as to their crown architecture, basically adopting the architectural characteristics abovementioned (Horn, 1971). Later on, when studies on tropical tree architecture developed, this was considered a relatively heterogeneous group (Poorter \& Werger, 1999; Sterck et al., 2003), presenting a more dynamic than static architecture as previously thought. Poorter \& Werger (1999) did not find evidence that shade-tolerant species present a monolayered leaf distribution, and Sterck et al. (2003) found the shade-tolerant species Trophis mexicana growing towards an intermediate crown shape between narrow and wide rather than a wide shape.

In tropical rain forests, canopy is very dynamic owing to a high rate of gap formation by tree and branch falls (Denslow, 1987). Bongers \& Sterck (1998) hypothesized that shade-tolerant species are more flexible in their architecture than shade-intolerant species because they survive in a much wider range of light levels, but this is still not clear. However, Aiba \& Kohyama (1997) suggested that non-pioneer (shade-tolerant) species tend to show a limited crown architectural plasticity in response to light compared to pioneer ones (shade-intolerant).

The purpose of the present study is to shed more light on the variability of crown architecture of shade-tolerant species. In a broad sense, shade-tolerant species include understorey or sub-canopy individuals shorter than
$15 \mathrm{~m}$ high; mid-canopy species attain the mid position in the forest canopy; and canopy species reach or surpass the top canopy level. In order to provide more empirical background, the allometry (architectural change through the individual development) of three shade tolerant tree species was analyzed, two sub-canopy (more shade-tolerant) and one mid-canopy (less shade-tolerant) species. Although the three species are shade-tolerant, it was hypothesized that differences would be found in their crown architecture, and the intermediate-canopy species would display more differences.

\section{Materials AND Methods}

\section{Site AND SPECIES STUDIED}

This study was conducted at the Los Tuxtlas Biological Station (Universidad Nacional Autónoma de México), $18^{\circ} 34-18^{\circ} 36^{\prime} \mathrm{N}$, $95^{\circ} 04-95^{\circ} 09^{\prime} \mathrm{W}$, located in the southern part of the state of Veracruz, Mexico. The climate is warm and humid; the mean annual temperature is $25.1^{\circ} \mathrm{C}$ and the mean annual precipitation is 4,487 mm (Martínez-Sánchez, 1999). From November through February there is a high incidence of strong, cool, and humid winds coming from the north, locally called "nortes", and reaching velocities of up to $80 \mathrm{~km} \mathrm{~h}^{-1}$. They play an important role in the dynamics of this forest as they recurrently create canopy openings by causing trees and branches to fall (Martínez-Ramos, 1985).

A detailed description of the forest structure in this biological station was published by Bongers et al. (1988) and Popma et al. (1988). In the area there is a lowland tropical rain forest, characterized by a relatively low stem density (2,976 individuals presenting $\mathrm{dbh} \geq 1 \mathrm{~cm}$, and 346 individuals with $\mathrm{dbh} \geq 10 \mathrm{~cm}$ ). In a 1-ha plot, 234 species ( $\geq 0.5 \mathrm{~m}$ height) were recorded, among which $55.1 \%$ were trees, $9.4 \%$ shrubs, $3.4 \%$ palms, $20.1 \%$ vines, $6.8 \%$ herbs, and $5.1 \%$ unidentified life-forms. Canopy strata cannot be clearly distinguished (Popma et al., 1988); however, Astrocaryum mexicanum, a palm tree, clearly dominates the forest understorey (up to $10 \mathrm{~m}$ ), and Pseudolmedia oxyphyllaria, a tree, dominates the middle storey or sub-canopy. A closed continuous canopy is present between $30 \mathrm{~m}$ and $35 \mathrm{~m}$ above the ground. 
Three arboreal species widely distributed in different microenvironments were selected for this study: 1) Guamia sp. ("colorado"), 3-7 (-10) $\mathrm{m}$ tall, an undetermined and perhaps undescribed understorey species of the Annonaceae family, which was earlier erroneously reported as Sapranthus microcarpus (Donn.Sm.) R.E.Fr. (Murray, 1993); 2) Pseudolmedia oxyphyllaria Donn.Sm. ("tomatillo", Moraceae), a mid-canopy species, 20-25 (-30) m tall, with dbh of 30-50 cm; 3) Trophis mexicana (Liebm.) Bur. ("ramoncillo", Moraceae), an understorey species 5-7 (-12) m tall (IbarraManríquez \& Sinaca-Colín 1995, 1996). Guamia sp., P. oxyphyllaria, and T. mexicana have simple alternate leaves, 5-15 cm long, and exhibit orthotropic and monopodial growth in the trunk and plagiotropic and monopodial growth in the branches. At the sapling stage, the three species are capable of surviving and growing in the shade.

For the three species, individuals between $50 \mathrm{~cm}$ and $300 \mathrm{~cm}$ tall and not presenting any apparent physical damage were selected: 74 for Guamia sp., 100 for P. oxyphyllaria, and
80 for T. mexicana. Only four individuals over $250 \mathrm{~cm}$ of Guamia sp. were selected which may not be adult trees. For each individual, several architectural variables were measured (Table 1).

Pearson product-moment correlations were performed for the architectural variables of each species to analyze the main allometric relationships. When an allometric relationship was significant for the three species, the three regression lines were statistically compared and plotted to see differences in their allometries or architectural behavior. The comparison of lines of allometric relationships of two or more species is a method that has been used by several authors (King, 1990; Kohyama \& Hotta, 1990) to compare the allometry of tree species regardless of their stature and light environment, since two saplings of the same height and located next to each other (the same light environment), with different crown types, would appear at the extremes of the line. Log-transformations were used to achieve normality. Statgraphics Plus 4.0 was used.

Table 1 - Architectural variables used in the analysis.

\begin{tabular}{|c|c|c|}
\hline Variable & Unit & Description \\
\hline Sapling height $(\mathrm{HT})$ & $\mathrm{cm}$ & $\begin{array}{l}\text { Measured from the ground to the top of the sa- } \\
\text { pling }\end{array}$ \\
\hline Stem diameter (SD) & $\mathrm{cm}$ & Measured $30 \mathrm{~cm}$ from the ground \\
\hline Trunk slenderness (TS) & - & $\mathrm{HT} / \mathrm{SD}$ \\
\hline Crown depth (CD) & $\mathrm{cm}$ & $\begin{array}{c}\text { Distance from the bottom-most branch to the top } \\
\text { of the sapling }\end{array}$ \\
\hline Vertical crown area (VCA) & $\mathrm{cm}^{2}$ & $\begin{array}{l}\text { Estimated as an ellipse }\left(0.25 *(\mathrm{D} 1+\mathrm{D} 2 / 2)^{*} \mathrm{CD}\right) \\
\text { (Sterck et al., 2003) }\end{array}$ \\
\hline Horizontal crown area (HCA) & $\mathrm{cm}^{2}$ & $\begin{array}{l}\text { Estimated with the two cross-section diame- } \\
\text { ters of the crown and calculated as an ellipse } \\
\qquad\left(0.25^{*} \mathrm{D} 1^{*} \mathrm{D} 2\right) \text { (Bongers et al., 1988) }\end{array}$ \\
\hline Crown slenderness (CS) & - & $\mathrm{HCA} / \mathrm{CD}$ \\
\hline Number of leaves (NL) & unit & Leaves longer than $3 \mathrm{~cm}$ \\
\hline Branch length (BL) & $\mathrm{cm}$ & $\begin{array}{l}\text { Length of the main branches along the stem, using } \\
\text { the mean value of all branches }\end{array}$ \\
\hline Cost of leaf support (CLS) & - & $\mathrm{BL} / \mathrm{NL}$ \\
\hline Horizontal crown self-shading (HS) & - & $\mathrm{NL} / \mathrm{HCA}$ \\
\hline Vertical crown self-shading (VS) & - & $\mathrm{NL} / \mathrm{VCA}$ \\
\hline
\end{tabular}




\section{Results}

P. oxyphyllaria presented the largest sapling height and crown depth (Table 2). Values for crown slenderness around 1.0 mean an almost spheric shape; above 1.0, a slenderer shape; and below 1.0, a flatter shape. Guamia sp. presented an almost spheric-shaped crown, P. oxyphyllaria, a slenderer shape, and T. mexicana, a flatter shape.

Although the saplings of the three arboreal species presented an increase in height, the trunk diameter increased more in Guamia sp., somewhat in T. mexicana, and showed no increment in P. oxyphyllaria. While the saplings of the three species showed an increase in height, their crown depth, horizontal crown area, vertical crown area, and number of leaves also increased, whereas the cost of leaf support decreased (Table 3). Both vertical and horizontal crown areas increased, which made the crown not adopt a clear flat or elongated form.

Horizontal and vertical leaf shading was reduced due to increments of horizontal and vertical crown area. Saplings grew in height, while vertical shading decreased only in P. oxyphyllaria and T. mexicana and horizontal shading did not change in the three species. As the number of leaves increased, bran- ch length, horizontal crown area, and vertical crown area also increased. The strong negative relationship between number of leaves and cost of leaf support indicates that, in the species studied, when more leaves grow in the crown, the investment of branch support decreases. Also, the increment of leaves did not reflect in crown self-shading (Table 3).

When comparing the species allometry by their regression lines, the most shadetolerant species (Guamia sp. and T. mexicana) tended to differ from the least shade-tolerant species (P. oxyphyllaria). As the saplings increased in height (HT), Guamia sp. increased more in stem diameter (SD) (Figure 1) and T. mexicana showed shorter crown depth (CD) (Figure 2) and vertical crown area (VCA) (Figure 3). While saplings height (HT) increased, vertical crown self-shading (VS) decreased more in P. oxyphyllaria and T. mexicana (Figure 4). Horizontal crown area (HCA) (Figure 5) and horizontal crown self-shading (HS) (Figure 6) were higher in Guamia sp. and T. mexicana, respectively. T. mexicana presented lower number of leaves (NL) (Figure 7) and higher cost of leaf support (CLS) (Figure 8) than the other species. Crown slenderness (CS) (Figure 9) was more pronounced in Guamia sp. and P. oxyphyllaria than in T. mexicana, which

Table 2 - Mean values (MV) and coefficients of variation (CV) for the architectural variables of three shade-tolerant species.

\begin{tabular}{|c|c|c|c|c|c|c|c|}
\hline \multirow{3}{*}{ Variable } & \multirow{3}{*}{ Unit } & \multicolumn{6}{|c|}{ Shade-tolerant species } \\
\hline & & \multicolumn{2}{|c|}{$\begin{array}{l}\text { Guamia sp. } \\
(\mathbf{N}=74)\end{array}$} & \multicolumn{2}{|c|}{$\begin{array}{l}\text { P. oxyphyllaria } \\
(\mathrm{N}=100)\end{array}$} & \multicolumn{2}{|c|}{$\begin{array}{l}\text { T. mexicana } \\
(\mathrm{N}=80)\end{array}$} \\
\hline & & Mean & CV(\%) & Mean & CV(\%) & Mean & $\mathrm{CV}(\%)$ \\
\hline HT & $\mathrm{cm}$ & 131.66 & 46 & 153.52 & 39 & 122.85 & 33 \\
\hline TS & - & 132.91 & 27 & 148.82 & 27 & 170.04 & 23 \\
\hline CD & $\mathrm{cm}$ & 71.92 & 52 & 83.43 & 52 & 60.88 & 50 \\
\hline VCA & $\mathrm{cm}^{2}$ & 5,400 & 65 & 5,700 & 54 & 2,300 & 39 \\
\hline HCA & $\mathrm{cm}^{2}$ & 7,800 & 141 & 7,700 & 84 & 2,300 & 137 \\
\hline CS & - & 0.99 & 78 & 1.29 & 65 & 0.87 & 114 \\
\hline NL & - & 120.16 & 89 & 109.64 & 70 & 50.73 & 112 \\
\hline CLS & - & 0.46 & 57 & 0.45 & 51 & 1.09 & 75 \\
\hline HS & - & 231.0 & 70 & 182.0 & 70 & 341.0 & 79 \\
\hline VS & - & 270.0 & 52 & 230.0 & 65 & 350.0 & 103 \\
\hline
\end{tabular}


Table 3 - Allometric Pearson correlations (r) for the three species. Most correlations were improved using log-transformation.

\begin{tabular}{|c|c|c|c|}
\hline Variable & Guamia sp. & P. oxyphyllaria & T. mexicana \\
\hline HT vs. SL & $-0.507^{* * *}$ & n.s. & $-0.207^{*}$ \\
\hline HT vs. CD & $0.852 * * *$ & $0.784^{* * *}$ & $0.742^{* * *}$ \\
\hline HT vs. VCA & $0.751^{* * *}$ & $0.752^{* * *}$ & $0.758^{* * *}$ \\
\hline HT vs. VS & n.s. & $-0.269^{* *}$ & $-0.220^{*}$ \\
\hline HT vs. HCA & $0.574^{* * *}$ & $0.524^{* * *}$ & $0.428^{* * *}$ \\
\hline HT vs. HS & n.s. & n.s. & n.s. \\
\hline HT vs. LN & $0.799^{* * *}$ & $0.740^{* * *}$ & $0.744^{* * *}$ \\
\hline HT vs. CLS & $-0.663^{* * *}$ & $-0.441^{* * *}$ & $-0.313^{* *}$ \\
\hline HT vs. CS & $0.392^{* *}$ & n.s. & $0.345^{* *}$ \\
\hline HCA vs. VCA & $0.541^{* * *}$ & $0.697^{* * *}$ & $0.524^{* * *}$ \\
\hline HCA vs. HS & $-0.375^{* *}$ & $-0.374^{* * *}$ & $-0.286^{*}$ \\
\hline VCA vs. VS & $-0.407^{* *}$ & $-0.397^{* *}$ & $-0.233^{*}$ \\
\hline LN vs. BL & $0.654^{* * *}$ & $0.572^{* * *}$ & $0.692^{* * *}$ \\
\hline LN vs. HCA & $0.755^{* * *}$ & $0.743^{* * *}$ & $0.893^{* * *}$ \\
\hline LN vs. VCA & $0.712^{* * *}$ & $0.789^{* * *}$ & $0.817^{* * *}$ \\
\hline LN vs. CLS & $-0.818^{* * *}$ & $-0.828^{* * *}$ & $-0.859^{* * *}$ \\
\hline LN vs. HS & n.s. & n.s. & n.s. \\
\hline LN vs. VS & n.s. & n.s. & n.s. \\
\hline
\end{tabular}

${ }^{* * *}=\mathrm{P}<0.0001 ;{ }^{* *}=\mathrm{P}<0.001 ;{ }^{*}=\mathrm{P}<0.05 ;$ n.s. $=$ non-significant.

almost did not change throughout the period of sapling growth. Reduction of vertical crown self-shading (VS) was more pronounced in $T$. mexicana and P. oxyphyllaria than in Guamia sp (Figure 10). All the figures show the comparison of regression lines of the form $\log (Y)=a+$ b $(\log (X))$ for saplings architectural variables (X, Y) of Guamia sp., P. oxyphyllaria, and T. mexicana. Lines with different superscripts differ in their slope or intersection at $\mathrm{Y}$ axis, so that it is possible to compare the allometry between the three species throughout a height range of saplings from $50 \mathrm{~cm}$ to $300 \mathrm{~cm}$.

\section{Discussion}

A flat crown form was not observed in the three shade-tolerant tree species evaluated; however, increments of crown depth were evident, indicating that relative high light levels could occur in the forest floor so that the sapling carbon balance can maintain middle or bottom branches in the crown. The increment of leaves in the three species did not reflect in crown self-shading, since crown depth, horizontal crown area, and increment of interbranch distance appeared as a clear strategy to reduce horizontal and vertical leaf shading.

To optimize growth, while increasing their leaf number, species chose to minimize their crown self-shading enlarging their horizontal crown area and distance among main branches instead of producing more branches. Studying rain forest saplings, Sterck et al. (2003) also reported the decrease of horizontal crown shading, the increment of crown size, as well as no effect of the leaves on selfshading. Thus, this crown adaptation may be 


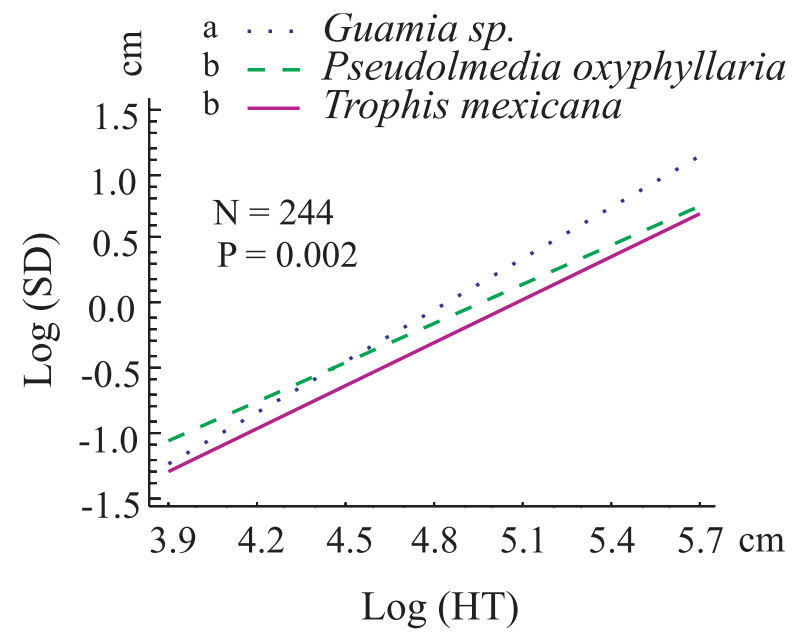

Figure 1 - Comparison of regression lines for saplings stem diameter (SD) and height (HT).

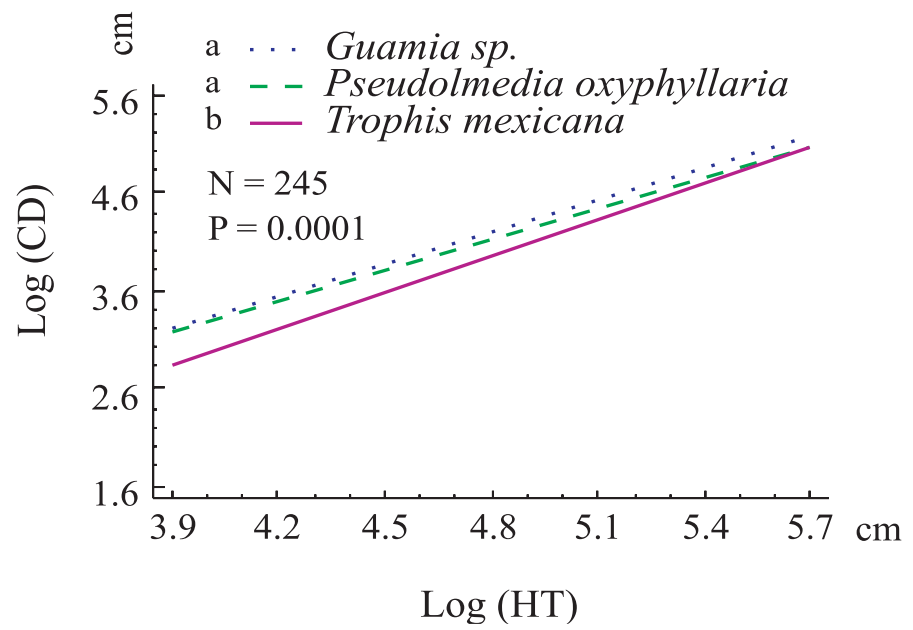

Figure 2 - Comparison of regression lines for saplings crown depth (CD) and height (HT).

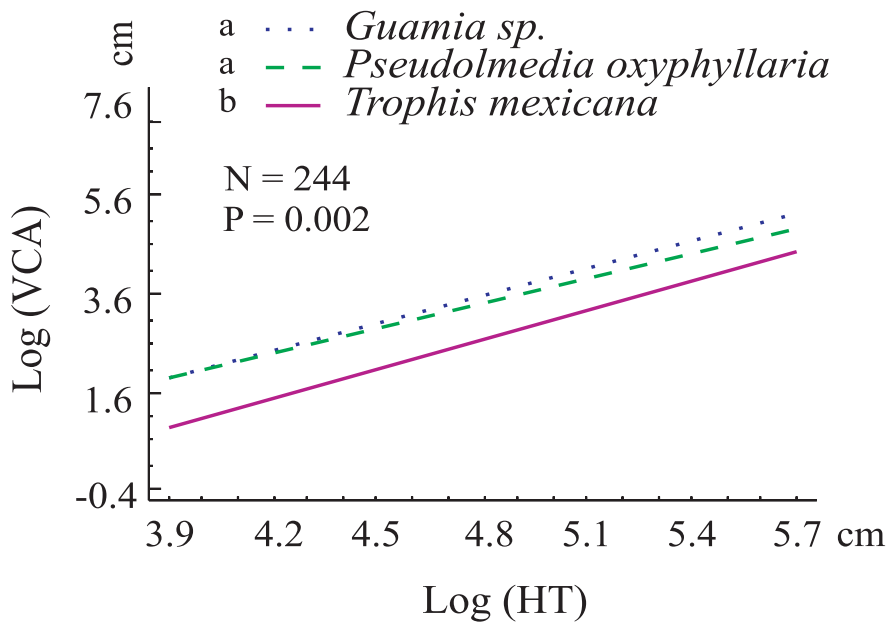

Figure 3 - Comparison of regression lines for saplings vertical crown area (VCA) and height (HT). 


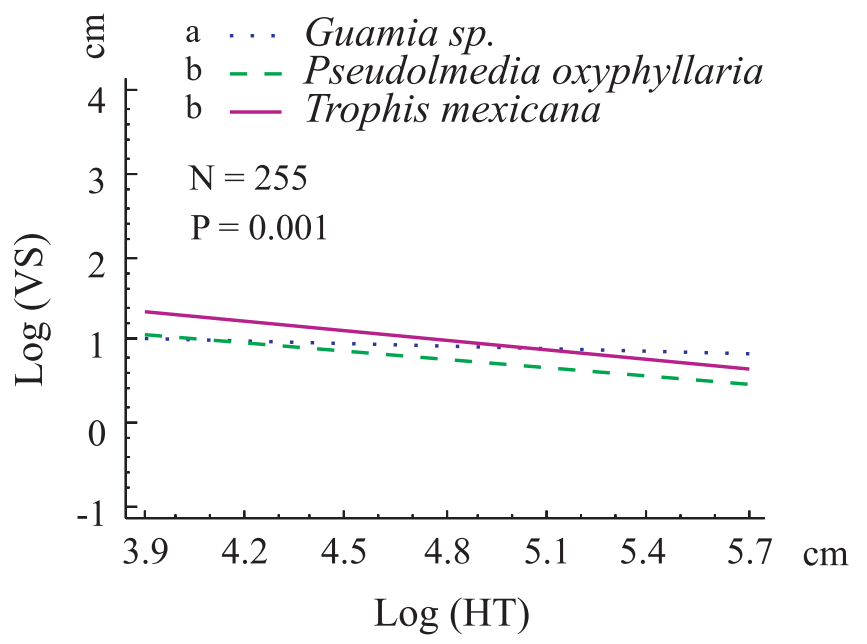

Figure 4 - Comparison of regression lines for saplings vertical crown self-shading (VS) and height (HT).

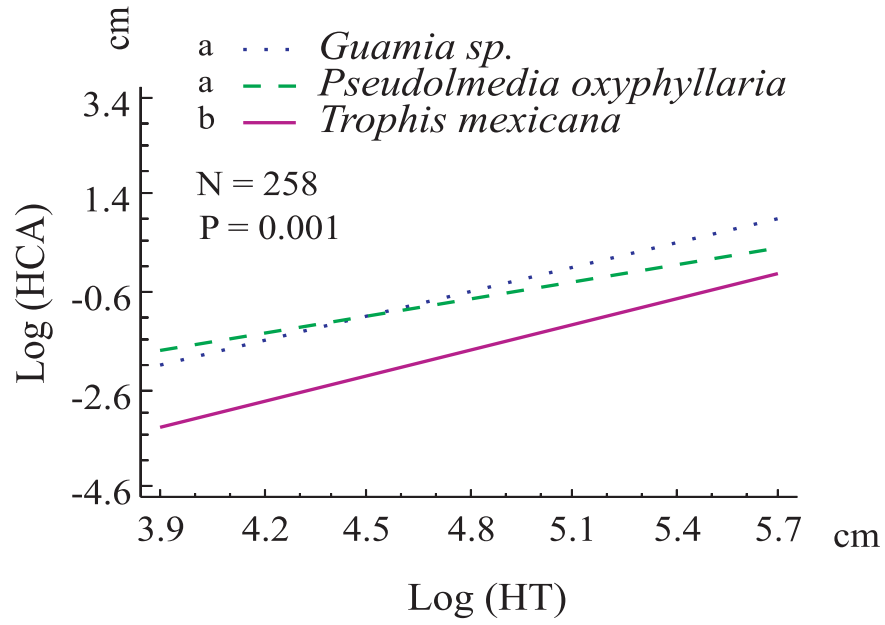

Figure 5 - Comparison of regression lines for saplings horizontal crown area (HCA) and height (HT).

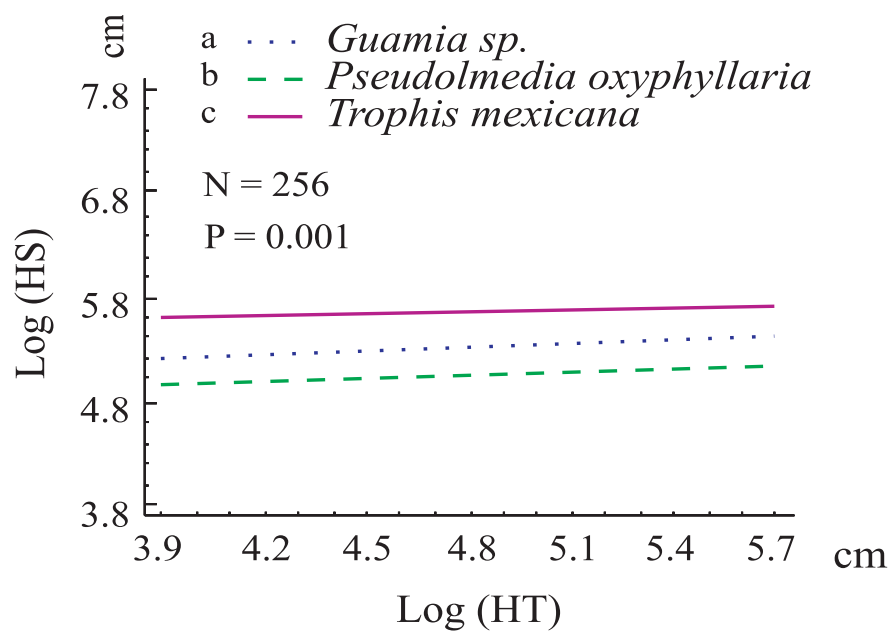

Figure 6 - Comparison of regression lines for saplings horizontal crown self-shading (HS) and height (HT). 


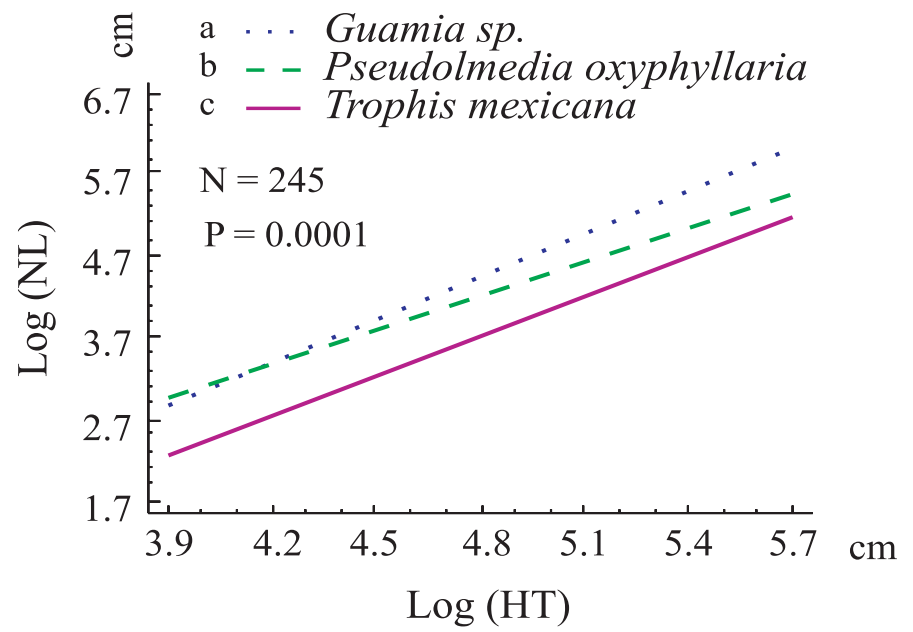

Figure 7 - Comparison of regression lines for saplings number of leaves (NL) and height (HT).

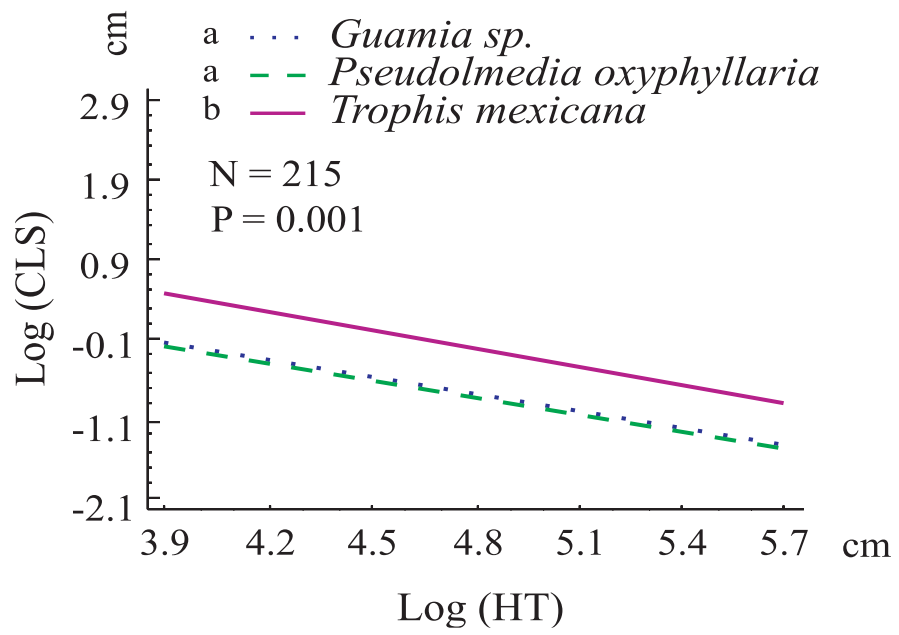

Figure 8 - Comparison of regression lines for saplings cost of leaf support (CLS) and height (HT).

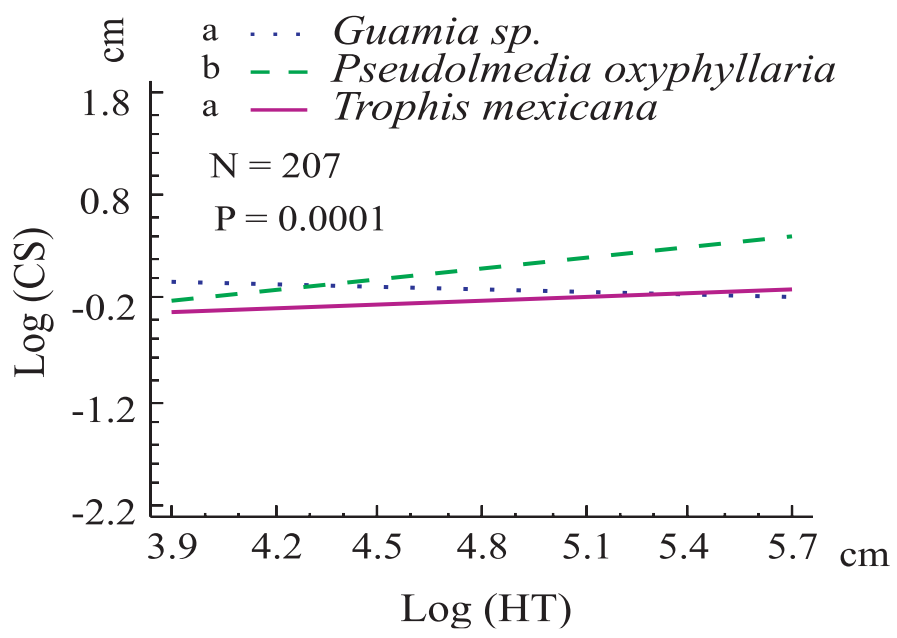

Figure 9 - Comparison of regression lines for saplings crown slenderness (CS) and height (HT). 


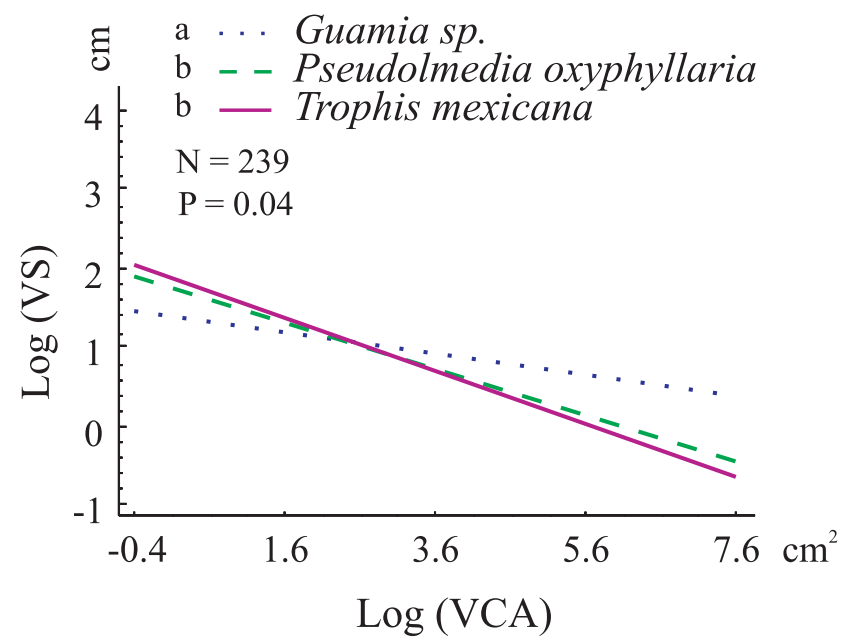

Figure 10 - Comparison of regression lines for saplings vertical crown self-shading (VS) and vertical crown area (VCA).

common for tropical saplings. However, the trait of horizontal shading had no effect on sapling growth and survival, indicating that self-shading does not necessarily bring about a negative carbon balance (Sterck et al., 2003). Height growth of juvenile sun-loving individuals and early-successional species generally results in larger crown depth (Shukla \& Ramakrishnan, 1986; King, 1990; Kohyama \& Hotta, 1990; Aiba \& Kohyama, 1997).

While saplings grew within a stature range of 50-300 cm, investment of non-photosynthetic leaf support tissue became more efficient, accommodating more leaves per unit of branch. The construction and maintenance of leaf-supporting structures, such as branches, require sizable investment in energy and materials (Chazdon, 1986). Then as saplings are growing, they optimize investment of non-photosynthetic tissue to relocate it to main shoots or roots.

High leaf production and short leaf longevity are present in sunny environments, the opposite occurring in shady environments (Bongers \& Popma, 1990). Thus lower costs of leaf support would be expected in sun-loving plants for competitive ability, and the opposite in shade-tolerant plants for survival ability.

From the three shade-tolerant species analyzed in this study, Guamia sp. and T. mexicana tended to differ from $P$. oxyphyllaria and seemed to be more shade-tolerant species (Figure 1). Stem architecture showed that
Guamia sp. was more shade-tolerant and presented a thicker stem than T. mexicana, whereas $P$. oxyphyllaria appeared as the least shadetolerant species with the highest stature and a slenderer trunk.

As shade-tolerant species, Guamia sp. presented increment of the crown size, with small reduction of its vertical crown shading, while T. mexicana showed a flatter or vertically compact crown, with a higher cost of leaf support. There are some evidences that different species use different crown traits with the common purpose of increasing sapling survival (Sterck et al., 2003). The least shade-tolerant species, P. oxyphyllaria, showed relatively slenderer trunk and crown and less vertical leaf shading. As the vertical crown area increased, the vertical leaf shading decreased more in P. oxyphyllaria than in Guamia sp., perhaps conferring the former higher growth ability as a less shade-tolerant species. The capture of diffuse or lateral light beneath the forest canopy is particularly important in shade-tolerant saplings for growth (Clearwater \& Gould, 1995). Overstorey species invest more in height and understorey species, in diameter (Kohyama \& Hotta 1990; King, 1994; O'Brian et al., 1995).

The analysis shows that, as the three species studied are shade-tolerant, there is some variability in their crown architecture, which somehow relates to their adult canopy position and growth habit. Differences in crown 
architecture among the species were found between the shorter sub-canopy species Guamia sp. and T. mexicana and the mid-canopy and taller species P. oxyphyllaria. Sterck et al. (2003) previously found T. mexicana growing towards an intermediate crown shape, between narrow and wide. In the present study, crown slenderness of T. mexicana did not change throughout the sapling stage of 50-230 cm height, which is in accordance with the results observed by Sterck et al. (2003) (Figure 1).

It can be concluded that shade-tolerant species do not adopt the single monolayered or wide crown architectural type. Instead, there is some degree of variability related to the growth habit and position they attain in the forest canopy in their adult stage. This crown architecture variability seems clearly influenced by the forest canopy light levels received by the species throughout its growth (Bongers \& Sterck 1998; King, 1994).

\section{References}

Aiba, S. \& T. Kohyama. 1997. Crown architecture and life-history traits of 14 tree species in a warm-temperate rain forest: significance of spatial heterogeneity. J. Ecol. 5: 611-624.

Bongers, F. \& J. Popma. 1990. Leaf dynamics of seedlings of forest species in relation to canopy gaps. Oecologia 82: 122-127.

Bongers, F., J. Popma, J. Meave del Castillo \& J. Carabias. 1988. Structure and floristic composition of the lowland rain forest of Los Tuxtlas, México. Vegetatio 74: 55-80.

Bongers, F. \& F. Sterck. 1998. Architecture and development of rainforest trees: Responses to light variation. p. 125-161. In: D. M. Newbery, H. H. T. Prins \& N. D. Brown (Eds), Dynamics of tropical communities. 37th Symposium of the British Ecological Society. Oxford, Blackwell Science.

Chazdon, R. L. 1986. The costs of leaf support in understory palms: economy versus safety. Am. Nat. 127: 9-30.

Clearwater, M. J. \& K. S. Gould. 1995. Leaf orientation and light interception by juvenile Pseudopanax crassifolius (Cunn.) C. Koch in a partially shaded forest environment. Oecologia 104: 363-371.
Denslow, J. S. 1987. Tropical rain forest gaps and tree species diversity. Ann. Rev. Ecol. Syst. 18: 431-451.

Horn, H. S. 1971. The adaptive geometry of trees. Princeton University Press, Princeton.

Ibarra-Manríquez, G. \& S. Sinaca-Colín. 1995. Lista florística de la Estación de Biología Tropical "Los Tuxtlas", Veracruz, México. Rev. Biol. Trop. 43: 75-115.

Ibarra-Manríquez, G. \& S. Sinaca-Colín. 1996. Estación de Biología Tropical “Los Tuxtlas", Veracruz, México: Lista florística comentada (Mimosaceae a Verbenaceae) Rev. Biol. Trop. 44: 41-60.

King, D. A. 1990. Allometry of saplings and understorey trees of a Panamanian forest. Funct. Ecol. 4: 27-32.

King, D. A. 1994. Influence of light level on the growth and morphology of saplings in a Panamanian forest. Am. J. Bot. 81: 948-957.

King, D. A., E. G. Leigh, R. Condit, R. B. Foster \& S. P. Hubbell. 1997. Relationships between branch spacing, growth rate and light in tropical rain forest saplings. Funct. Ecol. 11: 627-635.

Kohyama, T. 1987. Significance of architecture and allometry in saplings. Funct. Ecol. 1: 399-404.

Kohyama, T. 1991. A functional model describing sapling growth under a tropical forest canopy. Funct. Ecol. 5: 83-90.

Kohyama, T. \& M. Hotta. 1990. Significance of allometry in tropical saplings. Funct. Ecol. 4: 515-521.

Martínez-Ramos, M. 1985. Claros, ciclos vitales de los tropicales y la regeneración de las selvas altas perennifolias. p.191-239. In: A. Gómez-Pompa \& S. del Amo (Eds), Investigaciones sobre la regeneración de selvas húmedas tropicales en México. Vol. II. Alhambra. México D.F.

Martínez-Sánchez, J. L. 1999. Aspects of tropical rain forest and pasture nutrient dynamics at Los Tuxtlas, Mexico. Ph.D. Dissertation, University of Stirling, Stirling.

Murray, N. A. 1993. Revision of Cymbopetalum and Porcelia (Annonaceae). Syst. Bot. Monogr. 40: 1-121. 
O'Brian, S. T., S. P. Hubbell, P. Spiro, R. Condit \& R. Foster. 1995. Diameter, height, crown, and age relationship in eight neotropical tree species. Ecology 76: 1926-1939.

Poorter, L. \& M. J. A. Werger. 1999. Light environment, sapling architecture, and leaf display in six rain forest tree species. Am. J. Bot. 86: 1464-1473.

Popma, J., F. Bongers \& J. Meave del Castillo. 1988. Patterns in the vertical structure of the tropical lowland rain forest of Los Tuxtlas, México. Vegetatio 74: 81-91.
Shukla, R. P. \& P. S. Ramakrishnan. 1986. Architecture and growth strategies of tropical trees in relation to successional status. J. Ecol. 74: 33-46.

Sterck, F. J., M. Martínez-Ramos, G. Dyer-Leal, J. Rodríguez-Velázquez \& L. Poorter. 2003. The consequences of crown traits for the growth and survival of tree saplings in a Mexican lowland rainforest. Funct. Ecol. 17: 194-200.

Turner, I. M., W. K. Gong, J. E. Ong, J. S. Bujang \& T. Kohyama. 1995. The architecture and allometry of mangrove saplings. Funct. Ecol. 9: 205-212.

Recebido em 20/XII/2007

Aceito em 4/VII/2008 
